\title{
Peningkatan Pemahaman Budaya Kerja Masyarakat Jepang bagi Siswa SMK Yadika 13 Bekasi
}

\author{
Onin Najmudin ${ }^{1}$, Elli Rahmawati Zulaeha², Ani Sunarni ${ }^{3}$, \\ Novita Puspahaty ${ }^{4}$, Shabrina Rahmalia ${ }^{5}$ \\ STBA JIA ${ }^{1,2,3}$, Universitasi Islam ' $45^{4}$, STBA JIA ${ }^{5}$ \\ Korespondensi: oninn16@gmail.com ${ }^{1}$, elli.rahmati@gmail.com ${ }^{2}$, anasani12@gmail.com ${ }^{3}$, \\ novita@englishunisma.org ${ }^{4}$, shabrinarahmalia07@gmail.com ${ }^{5}$
}

\begin{abstract}
The ability to understand the culture of a particular community is a valuable asset in order to be able to interact and adapt to the community. As well as the understanding of the work culture of Japanese people. The purpose of our Community Service activity is to provide an understanding of the Japanese work culture to the students of SMK YADIKA 13 Kabupaten Bekasi. This activity will be followed by students from four different departments which are: (1) Department of Computer Network Engineering (TKJ), Department of Automated Light Vehicle Engineering (TKRO), Office Administration Automation Course (OTKP), and Department of Institutional Financial Accounting (AKL). The methods among others that will be used are: material about work culture in Japanese companies, (2) Japanese sundries, and (3) work opportunities in Japan. Results from the activities can be seen in the growing enthusiasm from the students of SMK Yadika 13 to work with Japanese companies in Indonesia and also working in Japan. Furthermore, this activity also has an impact on the emergence of interest in students to continue their education to universities related to Japan.
\end{abstract}

Keywords: community service, Japanese people, understanding, work culture, SMK YADIKA 13

\begin{abstract}
Abstrak
Kemampuan memahami budaya merupakan modal berharga agar dapat berinteraksi dan beradaptasi dengan komunitas masyarakat tersebut. Kegiatan berupa pengabdian kepada masyarakat ini bertujuan untuk memberikan pemahaman tentang budaya kerja masyarakat Jepang kepada siswa/I SMK Yadika 13 Kabupaten Bekasi. Kegiatan ini diikuti oleh siswa/I dari empat jurusan yang berbeda, di antaranya: (1) Jurusan Teknik Komputer Jaringan (TKJ), Jurusan Teknik Kendaraan Ringan Otomatis (TKRO), Jurusan Otomatisasi Tata Kelola Perkantoran (OTKP), dan Jurusan Akuntansi Keuangan Lembaga (AKL). Metode yang digunakan antara lain: (1) materi tentang budaya kerja di perusahaan Jepang, (2) serba serbi Jepang, dan (3) kesempatan bekerja di Jepang. Hasil dari kegiatan ini tampak pada munculnya antusiasme siswa SMK Yadika 13 untuk bekerja di perusahaan Jepang yang ada di Indonesia maupun bekerja di Jepang. Selain itu, kegiatan ini juga berdampak pada munculnya minat siswa untuk melanjutkan pendidikan ke perguruan tinggi yang berhubungan dengan Jepang.
\end{abstract}

Kata kunci: PkM, orang Jepang, meningkatkan pemahaman, budaya kerja, SMK YADIKA 13 
Onin Najmudin, Elli Rahmawati Zulaeha, Ani Sunarni, Novita Puspahaty \& Shabrina Rahmalia

\section{A. Pendahuluan}

Setiap negara memiliki ciri khas berupa budaya yang berfungsi sebagai identitas (jati diri) sekaligus sebagai norma dalam menjalankan rutinitas sehari-hari. Sebagai sebuah norma, budaya merupakan alat untuk mengatur perilaku seseorang dalam suatu komunitas, masyarakat, dan organisasi. Dari perspektif perilaku, Bodley (1994) mengklasifikasikan budaya sebagai pegangan hidup (a way of life), sebuah perilaku yang dapat dipelajari (learned human behavior), dan bersifat turun temurun. Demikian juga dengan budaya kerja yang dianut oleh masyarakat Jepang. Budaya kerja masyarakat Jepang yang dikenal dengan etos kerja dan disiplin yang tinggi menjadikan Jepang sebagai salah satu negara maju dalam bidang ilmu pengetahuan dan teknologi. Dengan kondisi tersebut, pilihan untuk berkarier dan memiliki pekerjaan di Jepang menjadi impian sebagian besar pembelajar bahasa Jepang di Indonesia.

Tingginya animo generasi muda Indonesia, khususnya pelajar bahasa Jepang di tingkat SMA dan SMK untuk berkarir dan bekerja di Jepang telah direspon dengan baik oleh pemerintah Indonesia dan Jepang melalui kerja sama ketenagakerjaan. Sejak April 2019, pemerintah Indonesia dan Jepang telah bersepakat menjalin kerja sama dalam bentuk Memorandum of Cooperation (MoC) dan Memorandum of Understanding (MoA) tentang penempatan tenaga kerja asal Indonesia untuk bekerja di Jepang melalui program Spesified Skilled Worker (SSW) atau tenaga kerja yang memiliki keterampilan spesifik. Pekerja Berketerampilan Spesifik merupakan sebuah program yang memberikan status izin tinggal bagi orang asing untuk bekerja di Jepang sesuai dengan bidang keahliannya. Dengan kata lain, program ini memberikan keleluasaan izin tinggal bagi orang asing yang ingin bekerja dan menetap di Jepang. Pemerintah Jepang membuka dua jenis izin tinggal bagi Pekerja Berketerampilan Spesifik, yakni: (1) Pekerja Berketerampilan Spesifik (i), dan (2) Pekerja Berketerampilan Spesifik (ii). Kedua jenis izin tinggal tersebut memiliki kriteria masing-masing. Pekerja Berketerampilan Spesifik (i) memberikan keuntungan bagi mereka yang ingin bekerja di Jepang berupa: (1) Izin tingggal dan bekerja selama lima tahun, (2) Mendapatkan besaran gaji yang sama dengan orang Jepang, (3) Menerima pendidikan bahasa Jepang, (4) Menerima beragam bantuan (dukungan) dari perusahaan, dan (5) Tidak diperbolehkan membawa keluarga. Sementara itu, Pekerja Berketerampilan Spesifik (ii) memberikan keleluasaan bagi mereka yang bekerja di Jepang dalam hal izin tingggal berupa tidak ada batas waktu tinggal dan diperbolehkan membawa keluarga.

Jalinan kerja sama ketenagakerjaan antara Indonesia dan Jepang membuka peluang bagi generasi muda Indonesia untuk dapat berkarier dan bekerja di Jepang. Oleh karena itu, pemahaman tentang budaya Jepang, khususnya budaya kerja masyarakat Jepang menjadi aspek penting yang harus dipahami oleh pembelajar bahasa Jepang di tingkat SMA dan SMK yang ada di Kabupaten Bekasi. Berlandaskan latar belakang tersebut, maka tercetuslah inisiasi untuk berbagi pengetahuan tentang budaya kerja masyarakat Jepang melalui kegiatan Pengabdian kepada Masyarakat yang dilaksanakan oleh dosen dan mahasiswa STBA JIA bekerjasama dengan SMK Yadika 13 Kabupaten Bekasi.

ACITYA BHAKTI, Volume 2 Nomor 1, Februari 2022 
Sehubungan dengan hal tersebut, pemahaman tentang budaya kerja masyarakat Jepang dinilai perlu untuk disosialisasikan serta dipelajari oleh masyarakat Indonesia, terutama angkatan kerja dan calon angkatan kerja seperti siswa SMK Yadika di Kabupaten Bekasi.

\section{1) Budaya}

Beragam nilai dan aspek yang terkandung dari sebuah budaya menjadikan istilah ini sulit untuk didefinisikan berdasarkan satu perspektif saja. Dalam rangka memahami definisi budaya secara utuh, Spencer-Oatey (2012) memberikan gambaran budaya berdasarkan beberapa karakteristik diantaranya: (1) Budaya termanifestasi pada tahapan yang berbeda-beda. Pada tahap ini budaya dapat berupa: (a) artefak yang dapat diamati, (b) nilai, dan (c) asumsi. (2) Budaya memengaruhi perilaku dan interpretasi perilaku. Pada tahap ini gambaran sebuah budaya dapat dilihat dari kebiasaan berupa komunikasi yang digunakan oleh komunitas atau masyarakat tertentu seperti bahasa tubuh (gesture) dan cara berpakaian. (3) Budaya dapat dibedakan dari sifat manusia yang universal dan kepribadian individu yang unik. Pada tahapan ini, budaya dianggap sebagai sesuatu yang dapat dipelajari, bukan diwariskan. Suatu kelompok atau komunitas masyarakat tertentu akan memiliki budaya yang berbeda-beda. Demikian pula dengan tiap individu karena perbedaan tersebut, maka budaya yang berbeda-beda dari tiap individu, kelompok maupun komunitas masyarakat tertentu dapat dipelajari oleh individu, kelompok maupun komunitas masyarakat yang lain. (4) Budaya memengaruhi proses biologis. Pada tahapan ini budaya, tanpa kita sadari, memengaruhi proses biologis kita misalnya bekerja, minum, dan membersihkan diri seperti mandi. Semua proses biologis tersebut dipengaruhi oleh budaya (lingkungan) kita. Cara bekerja, minum, dan membersihkan diri dari setiap individu, kelompok dan komunitas masyarakat membentuk budaya yang berbeda-beda. (5) Budaya diasosiasikan dengan kelompok masyarakat sosial tertentu. Pada tahapan ini budaya melekat pada satu golongan tertentu seperti negara, regional, etnis dan lain sebagainya. (6) Budaya merupakan konsep individu dan konsep sosial. (7) Budaya selalu menyebar baik secara sosial maupun secara individual, oleh karenanya sulit untuk menemukan gambaran utuh tentang budaya. (8) Budaya memiliki unsur universal berupa etika dengan ciri khas tersendiri. (9) Budaya dapat dipelajari. (10) Budaya tunduk pada perubahan zaman. (11) Budaya memiliki keterkaitan satu sama lain. (12) Budaya adalah konsep deskriptif bukan evaluatif.

\section{2) Budaya Kerja Masyarakat Jepang}

Sebagai sebuah negara yang terkenal dengan kedisiplinan dan etos kerja yang tinggi, tak mengherankan apabila Jepang menjadi salah satu negara terdepan dalam bidang ilmu pengetahuan dan teknologi. Kedisiplinan dalam bekerja serta tingginya etos kerja masyarakat Jepang menjadi budaya kerja yang dapat dilihat dari lima (5) keunikan tersendiri (Tam, 2020). Kelima budaya kerja tersebut antara lain: (1) jam kerja yang panjang, (2) minum-minum setelah bekerja, (3) sistem senioritas, (4) harmonisasi kerja dalam kelompok, dan (5) tempat bekerja yang tanpa sekat 
Onin Najmudin, Elli Rahmawati Zulaeha, Ani Sunarni, Novita Puspahaty \& Shabrina Rahmalia

(terbuka). Sementara itu, setiap orang Jepang memegang teguh prisip yang telah lama dijalankan oleh leluhur mereka seperti konsep kaizen dan bushido.

Kaizen merupakan istilah dalam bahasa Jepang yang memiliki makna 'continuous improvement' atau pembaharuan secara terus menerus. Kaizen berasal dari dua kata, yaitu 'kai' yang berarti 'terus menerus; berkelanjutan' dan 'zen' sendiri memiliki makna 'kebaruan; pembaharuan'. Konsep ini pertama kali diperkenalkan dan dikembangkan oleh Dr. W. Edwards Deming yang mengunjungi Jepang sesaat setelah Perang Dunia II. Pada saat itu, ekonomi Jepang mengalami peningkatan yang cukup signifikan setelah mengaplikasikan konsep ini sebagai bagian dari kehidupan masyarakat Jepang. Sementara itu, konsep bushido merupakan semangat.

\section{B. Pelaksanaan dan Metode}

Kegiatan Pengabdian kepada masyarakat dengan tema "Culture and Work at Abroad (Japan)" oleh dosen dan mahasiswa Sekolah Tinggi Bahasa Asing JIA dilaksanakan di SMK YADIKA 13, Kabupaten Bekasi. Kegiatan ini diselenggarakan selama tiga (3) hari, tanggal 27 - 29 April 2021, pukul 10.00 sampai dengan pukul 12.00 WIB secara daring dengan menggunakan media Google Meet. Peserta kegiatan ini adalah siswa/I SMK Yadika 13 yang terdiri dari beberapa jurusan yaitu: Jurusan Teknik Komputer Jaringan (TKJ), Jurusan Teknik Kendaraan Ringan Otomatis (TKRO), Jurusan Otomatisasi Tata Kelola Perkantoran (OTKP), dan Jurusan Akuntansi Keuangan Lembaga (AKL). Kurikulum yang digunakan oleh SMK Yadika 13 memuat bahasa Jepang sebagai salah satu pelajaran yang diberikan kepada semua siswa di setiap jurusan. Hal tersebut berdampak pada tingginya minat siswa/I SMK Yadika 13 untuk mengetahui, memahami, dan mendapatkan informasi tentang budaya kerja masyarakat Jepang.

Kegiatan hari pertama, Selasa, tanggal 27 April 2021, kegiatan Pengabdian kepada Masyarakat oleh dosen dan mahasiswa STBA JIA di SMK Yadika 13 jurusan Teknik Komputer Jaringan (TKJ) adalah sebuah webinar dengan tema "Bekerja di Luar Negeri". Materi webinar disampaikan oleh Elli Rahmawati Zulaeha, S.Pd., M.Si Hari. Hari kedua, Rabu, tanggal 28 April 2021, materi webinar disampaikan kepada siswa/I jurusan Teknik Kendaraan Ringan Otomatis (TKRO) dengan pemateri Anggiarini Arianto, S.S., M.Hum. Pelaksanaan Pengabdian hari terkahir, Kamis, tanggal 29 April 2021, materi tentang budaya kerja masyarakat Jepang diberikan kepada siswa/I jurusan Otomatisasi Tata Kelola Perkantoran (OTKP) dan jurusan Akuntansi Keuangan Lembaga (AKL) dengan pemateri dari dosen STBA JIA, Onin Najmudin, S.S., M.Hum.

Materi-materi yang disampaikan oleh semua pemateri pada pelaksanaan Pengabdian kepada Masyarakat di SMK Yadika 13 merupakan usaha dalam meningkatkan pemahaman siswa/I SMK Yadika 13 tentang bagaimana budaya kerja perusahaan Jepang maupun budaya kerja masyarakat Jepang. Usaha ini tidak lepas dari tingginya minat masyarakat Indonesia untuk dapat bekerja di Jepang. Dengan informasi, pengetahuan, dan pemahaman tentang budaya kerja perusahaan Jepang maupun masyarakat Jepang yang disampaikan dalam kegiatan ini, diharapkan dapat menjadi bekal pengetahuan dan pemahaman bagi siswa/I SMK Yadika 13 yang

ACITYA BHAKTI, Volume 2 Nomor 1, Februari 2022 
memiliki minat bekerja di luar negeri, khususnya Jepang. Selain kemampuan bahasa, pengetahuan dan pemahaman tentang budaya kerja masyarakat Jepang merupakan salah satu yang harus dikuasai oleh mereka yang memiliki minat bekerja di Jepang agar mampu beradaptasi dan bersosialisasi dengan masyarakat Jepang.

\section{Hasil dan Pembahasan}

Kegiatan Pengabdian kepada Masyarakat di SMK Yadika 13 yang dilaksanakan selama tiga (3) hari diisi oleh pemateri dosen dan mahasiswa STBA JIA dengan peserta siswa/I dari tiap jurusan yang berbeda-beda. Hari pertama, yaitu hari Selasa tanggal 27 April 2021 diisi oleh Elli Rahmawati Zulaeha, S.Pd., M.Si dengan peserta kegiatan adalah siswa/I jurusan Teknik Komputer Jaringan (TKJ) sebanyak 50 orang. Materi yang disampaikan pada pertemuan pertama adalah tentang dinamika bekerja di perusahaan Jepang. Susunan acara pada hari pertama adalah sebagai berikut:
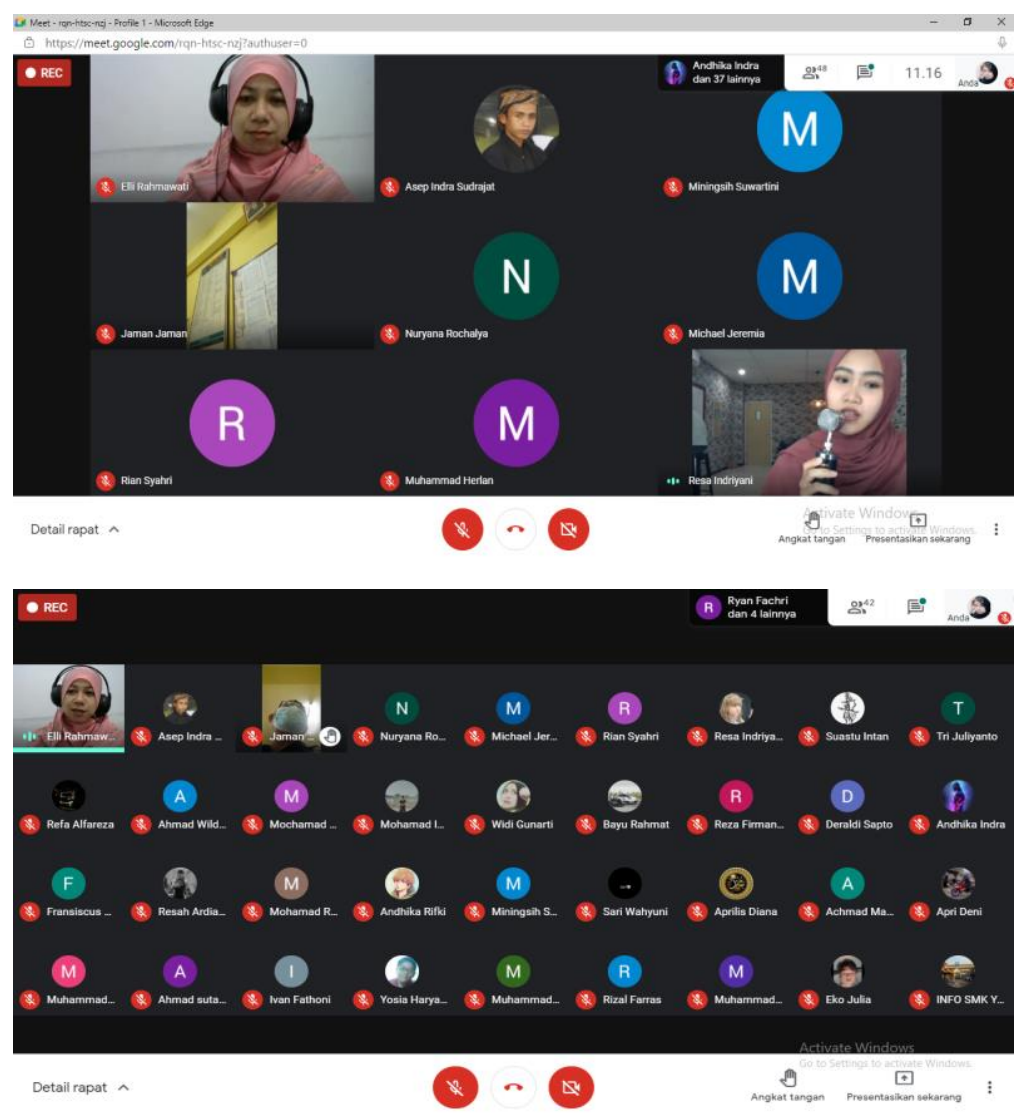

Gambar 1. Kegiatan pengabdian hari pertama

10.00-10.15 Sambutan Kepala Sekolah (Ibu Novita Yusnaini, S.S)

10.15-10.30 Sambutan Koordinator Keahlian Teknik Komputer Jaringan

10.30-11.30 Penyampaian Materi oleh Elli Rahmawati Zulaeha, S.Pd., M.Si

11.30-11.45 Materi Oleh Mahasiswa STBA JIA

11.45.12.00 Tanya Jawab 
Onin Najmudin, Elli Rahmawati Zulaeha, Ani Sunarni, Novita Puspahaty \& Shabrina Rahmalia

Materi yang disampaikan pada pertemuan pertama ini adalah berupa gambaran umum dinamika bekerja di perusahaan Jepang dan peluang-peluang untuk dapat bekerja di Jepang. Pemateri dalam penyampaiannya menekankan pentingnya beradaptasi dan dapat mengikuti ritme kerja masyarakat Jepang. Budaya kerja masyarakat Jepang menuntut kerja keras dan tingkat disiplin yang tinggi. Sementara itu, mahasiswa STBA JIA yang diwakili oleh Asep Indra Sudrajat, mahasiswa jurusan Bahasa Jepang (D3) menceritakan pengalamannya selama bekerja di Jepang. Dalam pemaparannya, dia menceritakan bagaimana suka duka selama bekerja di Jepang.
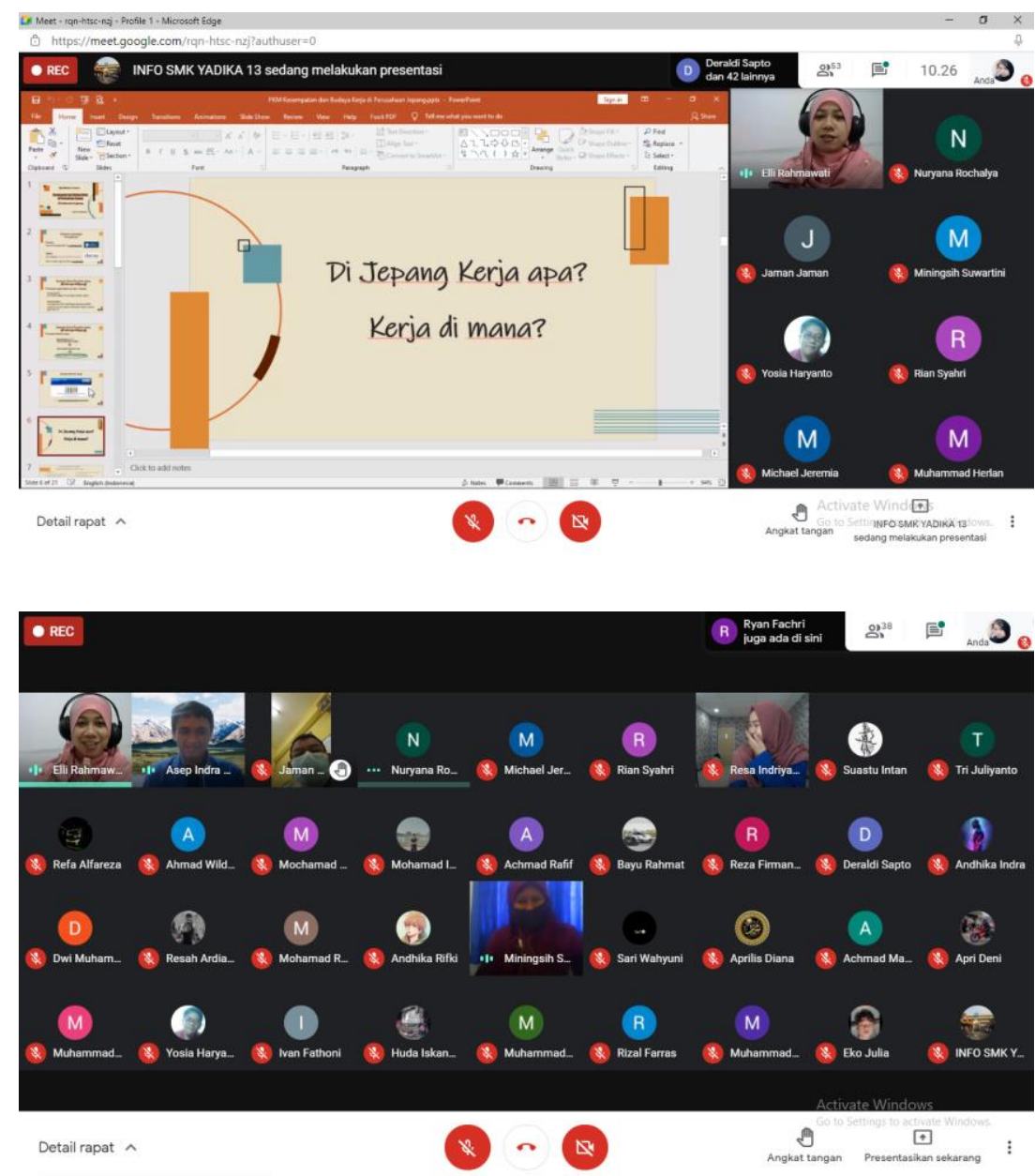

Gambar 2. Pelaksanaan pengabdian hari kedua

Hari kedua, pelaksanaan kegiatan pengabdian kepada masyarakat berupa materi tentang kesempatan bekerja di Jepang melalui lembaga-lembaga penyalur tenaga kerja seperti Lembaga Pelatihan Kerja (LPK), Balai Latihan Kerja (BLK) maupun lembaga resmi lainnya diberikan kepada siswa/I jurusan Teknik Kendaraan Ringan Otomatis (TKRO) yang dipaparkan oleh Anggiarini Arianto, S.S., M.Hum yang

ACITYA BHAKTI, Volume 2 Nomor 1, Februari 2022 
bertindak sebagai narasumber. Susunan acara pada hari kedua adalah sebagai berikut:

10.00-10.15 Pembukaan (Sambutan dari Siswa dan Guru SMK Yadika 13)

10.15-10.30 Sambutan Koordinator Keahlian Teknik Kendaraan Ringan Otomatis

10.30-11.30 Penyampaian Materi oleh Anggiarini Arianto, S.S., M.Hum

11.30-11.45 Materi Oleh Mahasiswa STBA JIA

11.45.12.00 Tanya Jawab

Materi tentang lembaga-lembaga resmi penyalur tenaga kerja ke Jepang seperti Lembaga Pelatihan Kerja (LPK) dan Balai Latihan Kerja (BLK) merupakan upaya dalam memberikan informasi kepada peserta kegiatan mengenai lembaga-lembaga dan prosedur-prosedur yang harus ditempuh jika memiliki minat bekerja ke Jepang. Hal tersebut dinilai penting mengingat Jepang adalah negara yang sangat ketat dalam menyeleksi pekerja asing yang akan bekerja di negara mereka. Selain itu, materi ini juga bermanfaat untuk mengantisipasi lembaga-lembaga atau penyalur tenaga kerja ilegal agar peserta kegiatan tidak terjebak oleh penyalur ilegal ketika hendak melamar kerja ke Jepang.

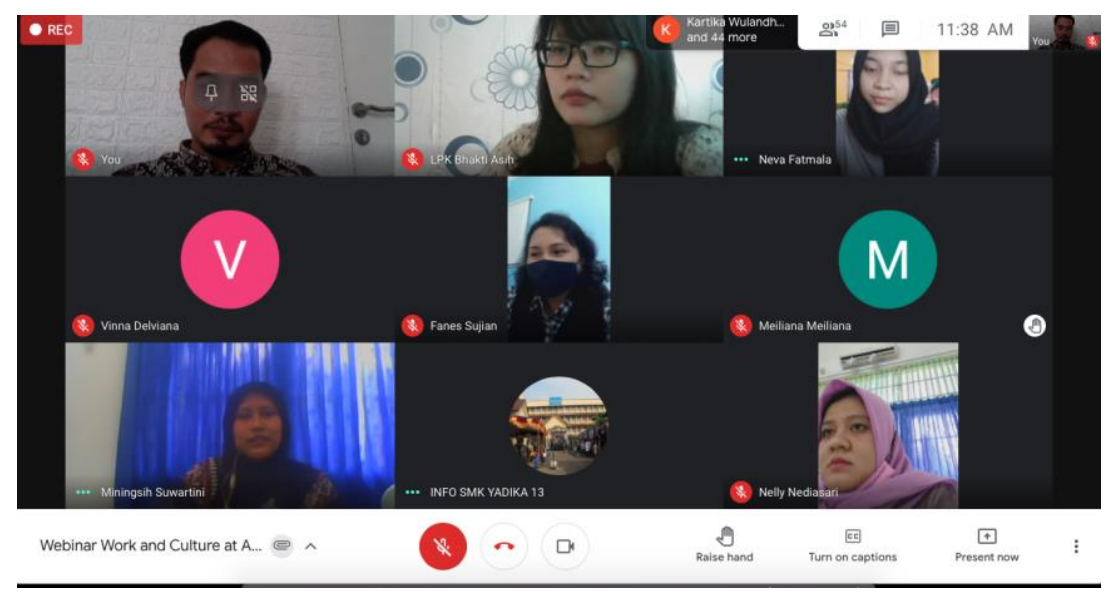

Gambar 3. Pelaksanaan pengabdian hari ketiga

Pelaksanaan Pengabdian kepada Masyarakat pada hari ketiga dilanjutkan dengan materi tentang budaya kerja, baik budaya kerja perusahaan maupun budaya kerja masyarakat Jepang. Materi ini disampaikan oleh Onin Najmudin, S.S., Hum kepada siswa/I jurusan Otomatisasi Tata Kelola Perkantoran (OTKP) dan jurusan Akuntansi Keuangan Lembaga (AKL). Peserta kegiatan di hari ketiga berjumlah lima puluh empat orang (54). Selain budaya kerja, materi yang diberikan kepada peserta di hari ketiga juga ditambahkan dengan informasi peluang kerja di Jepang yang disampaikan oleh mahasiswa STBA JIA, Rini Julia yang juga berprofesi sebagai tenaga pengajar sekaligus staf di Lembaga Pelatihan Kerja (LPK) Bhakti Asih, Tangerang. 
Onin Najmudin, Elli Rahmawati Zulaeha, Ani Sunarni, Novita Puspahaty \& Shabrina Rahmalia

Berikut merupakan susunan acara pengabdian kepada masyarakat pada hari ketiga:

10.00-10.15 Pembukaan (Sambutan dari Siswa dan Guru SMK Yadika 13)

10.15-10.30 Sambutan Koordinator Keahlian Akuntansi Keuangan Lembaga

10.30-11.30 Penyampaian Materi oleh Onin Najmudin, S.S., M.Hum

11.30-11.45 Materi Oleh Mahasiswa STBA JIA

11.45.12.00 Tanya Jawab

Pemahaman tentang budaya kerja perusahaan maupun budaya kerja masyarakat Jepang yang diberikan kepada peserta kegiatan adalah berupa falsafah yang dipegang dan digunakan masyarakat Jepang dalam bekerja maupun berinteraksi di tempat bekerja. Etos kerja berupa kaizen, bushido, meishi kokan, keisan, dan ganbatte merupakan budaya kerja yang menjadi ciri khas masyarakat Jepang. Pemahaman tentang lima etos kerja tersebut akan sangat berguna dalam berinteraksi dan beradaptasi dengan budaya kerja masyarakat Jepang. Sementara itu, informasi mengenai peluang kerja berupa persyaratan dan serangkaian ujian yang harus ditempuh sebelum berangkat kerja ke Jepang disampaikan oleh Rini Julia berdasarkan kriteria dan ketentuan yang digunakan di LPK Bhakti Asih.

Hasil dari pelaksanaan Pengabdian kepada Masyarakat di SMK Yadika 13 adalah upaya-upaya peningkatan pemahaman budaya kerja masyarakat Jepang oleh siswa-siswi SMK Yadika 13. Upaya untuk peningkatan pemahaman tampak dari pertanyaan-pertanyaan yang dikemukan siswa selama kegiatan berlangsung. Misalnya, pertanyaan tentang bagaimana cara agar mereka dapat beradaptasi di lingkungan kerja, baik itu di perusahaan Jepang maupun di Jepang sendiri. Pertanyaan tentang bagaimana upaya agar mereka dapat beradaptasi di perusahaan Jepang maupun ketika bekerja di Jepang dijelaskan oleh ibu Elli Rahmati Zulaekha adalah salah satunya dengan membiasakan diri menerapkan disiplin dalam setiap aktivitas keseharian. Hal tersebut merupakan upaya dalam beradaptasi dengan budaya kerja masyarkat Jepang, mengingat masyarakat Jepang terkenal dengan etos kerja yang tinggi dan sangat disiplin dalam setiap aspek kehidupan mereka.

Secara umum, kegiatan Pengabdian kepada Masyarakat yang dilakukan oleh dosen dan mahasiswa STBA JIA di SMK Yadika 13 Kabupaten Bekasi berjalan dengan baik dan memberikan sumbangsih keilmuan, terutama tentang pemahaman budaya kerja masyarakat Jepang bagi siswa-siswi sekolah tersebut. Adapun nilai positif lain adalah terjalinnya ikatan kerja sama antara dosen dan dewan guru di sekolah tersebut dalam membimbing dan mengarahkan siswa-siswi agar dapat bersaing di dunia kerja pada kemudian hari.

\section{Penutup \\ Simpulan}

Kegiatan Pengabdian kepada Masyarakat yang dilakukan oleh dosen dan mahasiswa STBA JIA di SMK Yadika 13 menghasilkan beberapa hal positif, baik bagi kedua institusi, dosen, mahasiswa, guru, dan terutama siswa/I SMK Yadika 13 sebagai peserta kegiatan. Bagi institusi, baik STBA JIA maupun SMK Yadika 13,

\footnotetext{
ACITYA BHAKTI, Volume 2 Nomor 1, Februari 2022
} 
kegiatan ini membuka jalinan kerja sama antar lembaga untuk menyelenggarakan kegiatan dalam bidang akademik maupun kegiatan non akademik di masa yang akan datang. Bagi dosen, guru, dan mahasiswa, kegiatan ini merupakan wadah silaturahmi dan mempererat jalinan komunikasi, baik sebagai individu maupun sebagai pendidik. Manfaat yang paling besar tentu saja didapatkan oleh semua siswa/I SMK Yadika 13 di setiap jurusan. Informasi dan pengetahuan yang mereka dapatkan dari kegiatan ini berupa pemahaman tentang budaya kerja masyarakat Jepang kemudian diharapkan menjadi sebuah pemahaman sekaligus bekal di masa yang akan datang.

\section{Saran}

Kegiatan Pengabdian kepada Masyarakat di SMK Yadika 13 dapat dijadikan sebagai pembuka kerja sama antar kedua institusi, yakni STBA JIA dengan SMK Yadika 13. Melalui kegiatan ini diharapkan dapat terlaksana kegiatan-kegiatan lain, baik akademik maupun non akademik antara STBA JIA dengan SMK Yadika 13. Selain itu, kegiatan Pengabdian kepada Masyarakat akan lebih optimal apabila dilaksanakan secara luring dengan durasi kegiatan dan agenda kegiatan yang lebih spesifik.

\section{DAFTAR PUSTAKA}

Bodley, H. J. (1994). Cultural anthropology: Tribes, states and the global system. Mayfield, CA. Mountain View.

Khan, I. A. (2011). KAIZEN: The Japanese strategy for continuous improvement. VSRD-IJBMR, 1(3), 177-184.

Spencer-Oatey, H. (2012). What is culture? A compilation of quotations. GlobalPAD Core Concepts. http://www2.warwick.ac.uk/fac/soc/al/globalpad/interculturalskills/

Tam, C. (2020). Work culture in Japan: The 5 crucial differences you should know about. Hive Life. https://hivelife.com/work-culture-japan/ 